\title{
USE OF SUNFLOWER MEAL IN FEED MIXTURES FOR LAYING HENS
}

\section{V. ŠERMAN, N. MAS, V. MELENJUK, F. DUMANOVSKI, Ž. MIKULEC}

Department of Animal Nutrition. Faculty of Veterinary Medicine, University of Zagreb. Jug Dubrovnik. Dubrovnik, and Poljoprerada d.d., Zagreb, Croatia

Received September 15, 1997

Accepted January 15, 1998

\begin{abstract}
Šerman V.. N. Mas, V. Melenjuk. F. Dumanovski. Ž. Mikulec: Use of Sunflower Meal in Feed Mixtures for Laying Hens. Acta vet. Brno 1997. 66: 219-227.

The nutritional effects of using decorticated sunflower meal ( $44 \%$ protein) as the protein supplement in the laying hens feed mixture on egg production were investigated. The trial was performed on 75 laying hens (line hybrid Issa brown) during the first 150 days of lay. The hens were divided in five groups: control, and four experimental groups ( 15 hens in each). The control group $(\mathrm{C})$ was fed on a commercial complete feed mixture (corn-soybean meal and fish meal). The experimental feed mixtures contained sunflower meal $\left(E_{l}\right)$, sunflower meal with correction of energy value by addition of sunflower oil $\left(E_{2}\right)$, sunflower meal with correction of lysine $\left(E_{3}\right)$ and sunflower meal with correction of energy value and lysine $\left(E_{t}\right)$.

The highest egg production was found in groups $E_{3}$ and $E_{4}$. The lowest consumption of feed was established in group $E_{1}$. while the highest consumption was found in groups $E_{3}$ and $C$. The highest increase in body mass was achieved in group $E_{4}$. The deficiency of lysine in sunflower meal $\left(E_{1}\right)$ contributed to lower body mass, feed consumption and egg mass. Feed mixtures containing sunflower meal as the protein supplement (all experimental groups) had no influence on the health or mortality of laying hens.

The results of this experiment indicate the possibility of a successfull use of sunflower meal in the nutrition of laying hens if sunflower meal is balanced with lysine and energy value.
\end{abstract}

Laying hens, sunflower meal, lysine, energy balance

Depending on local market, decorticated sunflower meal, obtained as a by-product in the sunflower seed oil production, might be a cheaper source of protein for poultry production than soybean meal and fish meal. However, low energy value and amino acid deficiency make the wider use of this feedstuff questionable.

Use of sunflower meal in feed mixtures in the production of laying hens has been the subject of numerous researches, but the results of this research differ greatly.

Ramirez et al. (1974) found that feed mixtures with 50 and $100 \%$ sunflower meal, as the only source of protein. increased feed consumption and decreased the laying capacity of Leghorn hens. Suljoti et al. (1986) concluded that substitution of fish meal with a mixture of soy and sunflower meal $(25,50$ and $100 \%)$ reduces egg production. In research reported by Kashani and Carlson (1988). 19 and $38 \%$ sunflower meal in the feed mixture decreased the body weight of 19-week-old pullets and delayed the onset of egg laying compared to control pullets fed on commercial feed mixture. De at on et al. (1979) observed that substituting soybean meal with sunflower meal increased the mass of the muscular gizzard but had no effect on change in body mass. egg production, egg mass, shell-breaking strength or mortality. Š okarovski et al. (1988) found that substituting soybean meal with sunflower meal had no negative effects on laying capacity, although it increased feed consumption per egg and decreased egg mass. According to Vieira et al. (1992) substitution of soybean meal with sunflower meal (13-45\%) in feed mixtures had no effect on laying capacity. egg mass, body mass and mortality of Issa brown hens. Addition of lysine in feed mixture (0.07-0.22\%) had a beneficial effect only on body mass gain. Investigating the potential for protein phase-feeding of laying hens, Nathanael and Sell (1980) found 
that daily intakes of $700 \mathrm{mg}$ of lysine were required for optimum performance (egg production, egg mass). Michel and Sunde (1985) evaluated sunflower meal as a replacement for soybean meal in pullet developer diets. In their experiment two sunflower meals (28 and $34 \%$ protein) with or without lysine completely replaced soybean meal. The addition of lysine to either of the two sunflower meals failed to improve growth and feed efficiency. When birds were housed in cages, the diets utilising $28 \%$ protein meal produced pullets smaller and less efficient than did the other diets. This effect was not observed when the floor management system was used. Cuca et al. (1973) found that in formulating rations containing sunflower meal for hens, lysine is the most limiting amino acid. Therefore in laying hen diets containing at least $5 \%$ sunflower meal, synthetic lysine must be used to provide the hen's daily requirements.

The purpose of this investigation was to evaluate the effect of sunflower meal as dietary protein source on laying hens (Issa brown) production performances (laying capacity, egg mass, feed consumption, body mass). Standard protein components (soybean and fish meal) were substituted by decorticated sunflower meal ( $44 \%$ protein). Due to high portion of decorticated sunflower meal, necessary to obtain the desired protein level in the mixture, the lysine content and energy value of the experimental mixtures were lower than those of the commercial one. Therefore, the amino acid deficiency of sunflower meal was overcome by supplementing lysine (two experimental groups) and the energy deficiency was made up (two experimental groups) by addition of sunflower oil to the diet.

\section{Materials and Methods}

Animals and diets

A total of 75 laying hens of the line hybrid Issa brown were divided into five groups (control and four experimental groups with 15 hens in each). Twenty-two-week-old laying hens were kept in cages (one hen to a cage) during the first five months of lay (150 days). The daily light and microclimatic conditions (temperature, air humidity and concentration of $\mathrm{NH}_{3}$ and $\mathrm{CO}_{2}$ ) met the technological and zoohygienic requirements for this line throughout the investigation. The health state of the hens was checked daily. All hens were included in the regular vaccination programme for laying hens of the line hybrid Issa brown.

Table 1

\section{Composition of the feed mixtures used in the trial}

\begin{tabular}{|l|c|c|c|c|c|}
\hline \multirow{2}{*}{ Compounds \% } & \multicolumn{5}{|c|}{ G R O U P S } \\
\cline { 2 - 5 } & $\mathrm{C}$ & $\mathrm{E}_{1}$ & $\mathrm{E}_{2}$ & $\mathrm{E}_{3}$ & $\mathrm{E}_{4}$ \\
\hline Maize & 65.50 & 62.30 & 57.80 & 62.00 & 58.50 \\
\hline Soybean meal (44\% CP) & 17.50 & - & - & - & - \\
\hline Fish meal & 4.00 & - & - & - & - \\
\hline Sunflower meal (44\% CP) & - & 24.00 & 24.80 & 24.00 & 24.00 \\
\hline Dehydrated Alfalfa meal & 3.00 & 3.00 & 3.00 & 3.00 & 3.00 \\
\hline Limestone & 7.00 & 7.00 & 7.00 & 7.00 & 7.00 \\
\hline Sunflower oil & 0.70 & 0.70 & 4.40 & 0.70 & 4.20 \\
\hline Dicalcium phosphate & 1.50 & 2.10 & 2.10 & 2.10 & 2.10 \\
\hline Salt & 0.30 & 0.40 & 0.40 & 0.40 & 0.40 \\
\hline Premix* & 0.50 & 0.50 & 0.50 & 0.50 & 0.50 \\
\hline Lysine & - & - & - & 0.30 & 0.30 \\
\hline Total & 100 & 100 & 100 & 100 & 100 \\
\hline
\end{tabular}

*Premix contained:

Feed grade premix for hens provided the following per kilogram: vitamin A, 2,000.000 IU; vitamin $D_{3}, 300,000$ IU; vitamin E, $4,000 \mathrm{mg}$; vitamin $\mathrm{K}_{3}, 400 \mathrm{mg} ; \mathrm{B}_{1}, 400 \mathrm{mg} ; \mathrm{B}_{2}, 1,000 \mathrm{mg} ; \mathrm{B}_{6}, 400 \mathrm{mg} ; \mathrm{B}_{12} 2,400 \mathrm{mcg}$; vitamin C, 2,000 mg; niacin, 6,000 mg; D-pantothenic acid, $1,500 \mathrm{mg}$; choline chloride, $95,000 \mathrm{mg}$; folic acid, $80 \mathrm{mg} ; \mathrm{Fe}, 6,000$ mg; Cu, 600 mg; Mn, 16,000 mg; J, 150 mg; Zn, 10,000 mg; Co, 20 mg; Se, 20 mg; methionine, 40,000 mg; BHA 
Feed and water were provided ad libitum. Composition of feed mixtures is given in Table 1. The control group (C) was fed a commercial complete feed mixture, whereas the mixtures for the experimental groups contained sunflower meal ( $44 \%$ crude protein, $3.36 \%$ crude fat, $8.42 \%$ crude fibre, $7370 \mathrm{~kJ} \mathrm{ME} / \mathrm{kg}$ ) as protein supplement. The experimental group $E_{1}$ received a feed mixture containing sunflower meal (without amino-acid and energy correction), $E_{2}$ sunflower meal with correction of energy value by addition of sunflower oil, $E_{3}$ sunflower meal with correction of amino-acid composition by addition of lysine, and $E_{4}$ sunflower meal with correction of both energy value and amino-acid composition.

Nutritive value and chemical composition of the control and experimental diets are given in Table 2.

Table 2

Nutritive values and chemical composition of the feed mixtures used in the trial

\begin{tabular}{|l|r|r|r|r|r|}
\hline \multirow{2}{*}{ Analysis as fed* } & \multicolumn{5}{|c|}{ G R O U P S } \\
\cline { 2 - 6 } & $\mathrm{C}$ & $\mathrm{E}_{1}$ & $\mathrm{E}_{2}$ & $\mathrm{E}_{3}$ & $\mathrm{E}_{+}$ \\
\hline Dry matter $\left(\mathrm{g} \cdot \mathrm{kg}^{-1}\right)$ & 880.0 & 878.0 & 878.8 & 875.5 & 880.0 \\
\hline Crude protein $\left(\mathrm{g} \cdot \mathrm{kg}^{-1}\right)$ & 160.5 & 160.5 & 160.4 & 163.2 & 160.4 \\
\hline Crude fat $\left(\mathrm{g} \cdot \mathrm{kg}^{-1}\right)$ & 36.4 & 40.0 & 75.4 & 39.9 & 73.5 \\
\hline Crude fibre $\left(\mathrm{g} \cdot \mathrm{kg}^{-1}\right)$ & 35.7 & 43.3 & 42.7 & 43.2 & 42.3 \\
\hline Ash $\left(\mathrm{g} \cdot \mathrm{kg}^{-1}\right)$ & 113.2 & 121.1 & 121.2 & 121.1 & 120.6 \\
\hline Calcium $\left(\mathrm{g} \cdot \mathrm{kg}^{-1}\right)$ & 33.8 & 34.7 & 34.7 & 34.7 & 34.7 \\
\hline Phosphorus $\left(\mathrm{g} \cdot \mathrm{kg}^{-1}\right)$ & 6.4 & 6.5 & 6.4 & 6.5 & 6.4 \\
\hline Natrium $\left(\mathrm{g} \cdot \mathrm{kg}^{-1}\right)$ & 1.7 & 1.7 & 1.7 & 1.7 & 1.7 \\
\hline Arginine $\left(\mathrm{g} \cdot \mathrm{kg}^{-1}\right)^{* *}$ & 9.4 & 11.2 & 11.3 & 11.2 & 11.1 \\
\hline Methionine $\left(\mathrm{g} \cdot \mathrm{kg}^{-1}\right)^{* *}$ & 3.5 & 3.7 & 3.8 & 3.7 & 3.7 \\
\hline Cystine $\left(\mathrm{g} \cdot \mathrm{kg}^{-1}\right)^{* *}$ & 2.5 & 2.7 & 2.7 & 2.7 & 2.7 \\
\hline Methionine $+\mathrm{Cystine}\left(\mathrm{g} \cdot \mathrm{kg}^{-1}\right)^{* *}$ & 6.0 & 6.4 & 6.5 & 6.4 & 6.4 \\
\hline Lysine** & 8.3 & 5.4 & 5.6 & 8.3 & 8.3 \\
\hline Tryptophan** & 1.6 & 1.6 & 1.6 & 1.6 & 1.6 \\
\hline ME $(\mathrm{MJ} / \mathrm{kg})$ & 11.45 & 10.63 & 11.44 & 10.64 & 11.45 \\
\hline
\end{tabular}

* Official methods were used throughout (A.O.A.C., 1984)

** Values of amino acids were calculated

Measuring of production results

The effect of sunflower meal in feed mixtures on laying capacity, egg mass, feed consumption, body mass and health of hens were observed.

Eggs were collected and weighed daily, with laying capacity being recorded for each month.

The feed consumption of each group was measured monthly, with results averaged per group, per hen and per egg.

Body mass was checked on the first day of the trial and subsequently every 30 days ( 5 measurements during the course of the trial) by individual weighing of all hens.

All results were subjected to statistical analysis (S patz 1997). The mean values of measured indices of each experimental group were compared with corresponding values of the control group; the significance of differences was assessed by Student's t-test $(\mathrm{P}<0.05)$.

\section{Results}

Feeding variables

Average final body mass and average body mass gain (Table 3 ) show that the best results in body mass gain (expressed in percentage as related to control group), were obtained in experimental group $\mathrm{E}_{4}(114.81 \%)$. Hens in experimental groups $\mathrm{E}_{2}$ and $\mathrm{E}_{3}$ had approximately the same body mass gain as the control group (102.88 and $103.7 \%)$, while the lowest gain was recorded in experimental group $\mathrm{E}_{1}(82.30 \%)$. These values are shown in Fig. 1 .

The highest average total feed consumption (Table 4) per group was recorded in experimental group $\mathrm{E}_{3}(258.30 \mathrm{~kg})$. Average total feed consumption in group $\mathrm{E}_{4}(249.00 \mathrm{~kg})$ 
was similar to that of the control group $(249.60 \mathrm{~kg})$. The smallest average total feed consumption was observed in groups $\mathrm{E}_{1}(238.80 \mathrm{~kg})$ and $\mathrm{E}_{2}(240.60 \mathrm{~kg})$.

Feed consumption per egg in groups $\mathrm{E}_{1}(118.16 \mathrm{~g}), \mathrm{E}_{4}(121.46 \mathrm{~g})$ and $\mathrm{E}_{2}(121.91 \mathrm{~g})$ was smaller than in the control group $(124.49 \mathrm{~g})$, while the highest value was found in group $\mathrm{E}_{3}$ (125.75 g).

Differences between control and experimental groups presented in Tables 3 and 4 were not statistically significant $(\mathrm{P}>0.05)$.

Table 3

Average body mass (g) and total body mass gain of laying hens during the trial

\begin{tabular}{|c|c|c|c|c|c|c|}
\hline \multirow{2}{*}{$\begin{array}{l}\text { Day of } \\
\text { trial }\end{array}$} & \multirow{2}{*}{$\begin{array}{l}\text { Stat. } \\
\text { data }\end{array}$} & \multicolumn{5}{|c|}{ Groups } \\
\hline & & $C(n=15)$ & $E_{1}(n=15)$ & $E_{2}(n=15)$ & $E_{3}(n=15)$ & $E_{4}(n=15)$ \\
\hline 1 & $\begin{array}{l}\mathrm{x} \\
\mathrm{s}\end{array}$ & $\begin{array}{l}1844 \\
180.55\end{array}$ & $\begin{array}{l}1820 \\
192.50\end{array}$ & $\begin{array}{l}1800 \\
179.40\end{array}$ & $\begin{array}{l}1828 \\
173.21\end{array}$ & $\begin{array}{l}1804 \\
158.17\end{array}$ \\
\hline 30 & $\begin{array}{l}\mathrm{x} \\
\mathrm{s}\end{array}$ & $\begin{array}{l}1865 \\
204.66\end{array}$ & $\begin{array}{l}1855 \\
198.99\end{array}$ & $\begin{array}{l}1876 \\
136.53\end{array}$ & $\begin{array}{l}1848 \\
152.65\end{array}$ & $\begin{array}{l}1858 \\
155.69\end{array}$ \\
\hline 60 & $\begin{array}{l}\mathrm{x} \\
\mathrm{s}\end{array}$ & $\begin{array}{l}1953 \\
192.23\end{array}$ & $\begin{array}{l}1887 \\
208.33\end{array}$ & $\begin{array}{l}1927 \\
168.89\end{array}$ & $\begin{array}{l}1967 \\
181.92\end{array}$ & $\begin{array}{l}1930 \\
161.25\end{array}$ \\
\hline 90 & $\begin{array}{l}\mathrm{x} \\
\mathrm{s}\end{array}$ & $\begin{array}{l}2027 \\
207.77\end{array}$ & $\begin{array}{l}1943 \\
227.75\end{array}$ & $\begin{array}{l}1933 \\
237.64\end{array}$ & $\begin{array}{l}2027 \\
221.09\end{array}$ & $\begin{array}{l}1997 \\
191.30\end{array}$ \\
\hline 120 & $\begin{array}{l}\mathrm{x} \\
\mathrm{s}\end{array}$ & $\begin{array}{l}2117 \\
257.51\end{array}$ & $\begin{array}{l}1953 \\
266.27\end{array}$ & $\begin{array}{l}2042 \\
216.49\end{array}$ & $\begin{array}{l}2086 \\
231.81\end{array}$ & $\begin{array}{l}2023 \\
212.02\end{array}$ \\
\hline 150 & $\begin{array}{l}\mathrm{x} \\
\mathrm{s}\end{array}$ & $\begin{array}{l}2087 \\
291.22\end{array}$ & $\begin{array}{l}2020 \\
264.44\end{array}$ & $\begin{array}{l}2050 \\
251.92\end{array}$ & $\begin{array}{l}2080 \\
256.91\end{array}$ & $\begin{array}{l}2083 \\
228.87\end{array}$ \\
\hline $\begin{array}{l}\text { Average } \\
\text { gain per }\end{array}$ & $\begin{array}{l}\text { ody mass } \\
\text { g) }\end{array}$ & 243 & 200 & 250 & 252 & 279 \\
\hline Index $\%$ & & 100 & 82.30 & 102.88 & 103.70 & 114.81 \\
\hline
\end{tabular}

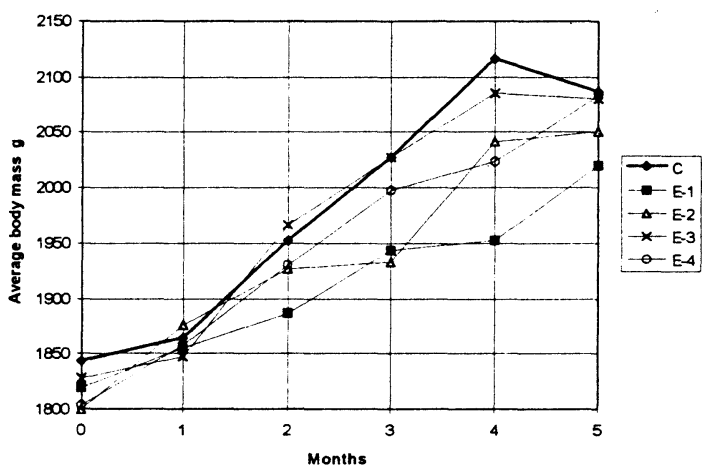

Fig. 1

Average body mass (g) of laying hens during the trial 
Table 4

Average total feed consumption during the trial

\begin{tabular}{|c|l|l|l|l|}
\hline & \multicolumn{2}{|c|}{ Total feed consumption } & \multicolumn{2}{c|}{ Feed consumption } \\
\hline \multirow{2}{*}{ Groups } & $\begin{array}{l}\text { per group } \\
(\mathrm{kg})\end{array}$ & $\begin{array}{l}\text { per hen } \\
(\mathrm{kg})\end{array}$ & $\begin{array}{l}\text { per egg } \\
(\mathrm{g})\end{array}$ & $\begin{array}{l}\text { per egg mass } \\
(\mathrm{kg} / \mathrm{kg})\end{array}$ \\
\hline $\mathrm{C}$ & 249.60 & 16.64 & 124.49 & 2.02 \\
\hline $\mathrm{E}_{1}$ & 238.80 & 15.92 & 118.16 & 1.92 \\
\hline $\mathrm{E}_{2}$ & 240.60 & 16.04 & 121.91 & 1.90 \\
\hline $\mathrm{E}_{3}$ & 258.30 & 17.22 & 125.75 & 1.97 \\
\hline $\mathrm{E}_{4}$ & 249.00 & 16.60 & 121.46 & 1.89 \\
\hline
\end{tabular}

\section{Egg production}

Average number of eggs per hen (Table 5) and average laying capacity (Table 6) during the trial were about the same in experimental groups $E_{3}$ (average number of eggs 136.93; laying capacity $91.74 \%)$ and $\mathrm{E}_{4}(136.67 ; 91.48 \%)$. Control $(\mathrm{C})$ and $\mathrm{E}_{1}$ groups produced a similar number of eggs (133.67 and 134.73) and had a similar laying capacity (89.44\% and $90.35 \%$ ), while the poorest values were found in group $\mathrm{E}_{2}(131.57 ; 88.01 \%)$. The differences between control and experimental groups were statistically non-significant (P>0.05).

Average egg mass (Table 7) in experimental groups $\mathrm{E}_{4}(64.36 \mathrm{~g}), \mathrm{E}_{2}(64.13 \mathrm{~g})$ and $\mathrm{E}_{3}(63.82 \mathrm{~g})$ was significantly higher $(\mathrm{P}<0.05)$ than in the control group $(61.65 \mathrm{~g})$. Average egg mass in experimental group $\mathrm{E}_{1}$ was about the same $(61.43 \mathrm{~g})$ as the control group.

Table 5

Average number of eggs during the trial/per hen

\begin{tabular}{|c|c|c|c|c|c|c|}
\hline \multirow{2}{*}{$\begin{array}{l}\text { Day of } \\
\text { trial }\end{array}$} & \multirow{2}{*}{$\begin{array}{l}\text { Stat. } \\
\text { data }\end{array}$} & \multicolumn{5}{|c|}{ Groups } \\
\hline & & $C(n=15)$ & $E_{1}(n=15)$ & $E_{2}(n=15)$ & $\mathrm{E}_{3}(\mathrm{n}=15)$ & $E_{4}(n=15)$ \\
\hline \multirow[t]{2}{*}{30} & $\mathrm{x}$ & $21.27 \pm 1.48$ & $24.40 \pm 1.83$ & $20.53 \pm 1.45$ & $23.60 \pm 1.27$ & $22.27 \pm 1.35$ \\
\hline & $\mathrm{s}$ & 5.71 & 7.08 & 5.60 & 4.90 & 5.24 \\
\hline \multirow[t]{2}{*}{60} & $\mathrm{x}$ & $28.60 \pm 0.67$ & $28.73 \pm 0.50$ & $28.60 \pm 0.51$ & $28.67 \pm 0.50$ & $29.20 \pm 0.30$ \\
\hline & $s$ & 2.61 & 6.77 & 1.99 & 1.92 & 1.15 \\
\hline \multirow[t]{2}{*}{90} & $\mathrm{x}$ & $28.67 \pm 0.57$ & $28.06 \pm 0.57$ & $26.87 \pm 1.80$ & $28.40 \pm 0.53$ & $29.40 \pm 0.47$ \\
\hline & s & 2.19 & 2.19 & 6.96 & 2.06 & 1.80 \\
\hline \multirow[t]{2}{*}{120} & $x$ & $30.13 \pm 0.70$ & $28.07 \pm 1.36$ & $30.14 \pm 0.70$ & $30.33 \pm 0.59$ & $30.20 \pm 0.61$ \\
\hline & $\mathrm{s}$ & 2.72 & 5.25 & 2.60 & 2.29 & 2.37 \\
\hline \multirow[t]{2}{*}{150} & $\mathrm{x}$ & $25.00 \pm 0.73$ & $25.47 \pm 0.81$ & $25.43 \pm 0.61$ & $25.93 \pm 0.77$ & $25.60 \pm 0.84$ \\
\hline & s & 2.83 & 3.14 & 2.28 & 2.99 & 3.25 \\
\hline \multirow[t]{2}{*}{ Average } & $\mathrm{x}$ & 133.67 & 134.73 & 131.57 & 136.93 & 136.67 \\
\hline & s & 7.06 & 14.02 & 12.34 & 8.51 & 8.66 \\
\hline
\end{tabular}


Table 6

Average laying capacity $(\%)$ during the trial

\begin{tabular}{|c|c|c|c|c|c|c|}
\hline \multirow{2}{*}{$\begin{array}{l}\text { Day of } \\
\text { trial }\end{array}$} & \multirow{2}{*}{$\begin{array}{l}\text { Stat. } \\
\text { data }\end{array}$} & \multicolumn{5}{|c|}{ Groups } \\
\hline & & $C(n=15)$ & $E_{1}(n=15)$ & $E_{2}(n=15)$ & $E_{3}(n=15)$ & $E_{4}(n=15)$ \\
\hline \multirow[t]{2}{*}{30} & $x$ & 75.95 & 87.14 & 73.33 & 84.29 & 79.52 \\
\hline & $\mathrm{s}$ & 20.41 & 25.29 & 20.03 & 17.46 & 18.74 \\
\hline \multirow[t]{2}{*}{60} & $\mathrm{x}$ & 92.25 & 92.69 & 92.26 & 92.47 & 94.19 \\
\hline & $\mathrm{s}$ & 8.52 & 6.23 & 6.37 & 6.23 & 3.77 \\
\hline \multirow[t]{2}{*}{90} & $\mathrm{x}$ & 95.56 & 93.56 & 89.56 & 94.67 & 98.00 \\
\hline & $\mathrm{s}$ & 7.25 & 7.23 & 23.17 & 6.84 & 6.03 \\
\hline \multirow[t]{2}{*}{120} & $\mathrm{x}$ & 97.20 & 90.54 & 97.24 & 97.84 & 97.42 \\
\hline & $\mathrm{s}$ & 8.85 & 16.94 & 8.32 & 7.51 & 7.64 \\
\hline \multirow[t]{2}{*}{150} & $\mathrm{x}$ & 86.26 & 87.82 & 87.68 & 89.43 & 88.28 \\
\hline & $\mathrm{s}$ & 9.73 & 10.79 & 7.90 & 10.26 & 11.18 \\
\hline Average & $\mathrm{x}$ & 89.44 & 90.35 & 88.01 & 91.74 & 91.48 \\
\hline
\end{tabular}

Table 7

Average egg mass mass (g) during the trial

\begin{tabular}{|c|l|c|c|c|c|c|}
\hline \multirow{2}{*}{$\begin{array}{l}\text { Day of } \\
\text { trial }\end{array}$} & \multirow{2}{*}{$\begin{array}{l}\text { Stat. } \\
\text { data }\end{array}$} & \multicolumn{5}{|c|}{$\mathrm{G} \mathrm{r} \mathrm{o} \mathrm{u} \mathrm{p}$} \\
\cline { 3 - 7 } & $\mathrm{C}(\mathrm{n}=15)$ & $\mathrm{E}_{1}(\mathrm{n}=15)$ & $\mathrm{E}_{2}(\mathrm{n}=15)$ & $\mathrm{E}_{3}(\mathrm{n}=15)$ & $\mathrm{E}_{4}(\mathrm{n}=15)$ \\
\hline \multirow{2}{*}{30} & $\mathrm{x}$ & 56.32 & 57.41 & 59.60 & 58.76 & 58.80 \\
& $\mathrm{~s}$ & 4.90 & 4.18 & 3.95 & 2.63 & 5.20 \\
\hline \multirow{2}{*}{60} & $\mathrm{x}$ & 61.23 & 62.04 & 64.19 & 64.30 & 64.88 \\
& $\mathrm{~s}$ & 4.61 & 3.80 & 3.98 & 4.30 & 3.87 \\
\hline 90 & $\mathrm{x}$ & 63.17 & 62.53 & 64.87 & 64.66 & 65.53 \\
& $\mathrm{~s}$ & 4.85 & 5.92 & 4.40 & 3.20 & 3.07 \\
\hline 120 & $\mathrm{x}$ & 63.92 & 62.53 & 65.94 & 65.64 & 66.11 \\
& $\mathrm{~s}$ & 5.20 & 4.04 & 3.69 & 2.94 & 4.77 \\
\hline 150 & $\mathrm{x}$ & 63.60 & 62.66 & 66.04 & 65.76 & 66.47 \\
& $\mathrm{~s}$ & 4.91 & 5.00 & 4.20 & 5.31 & 4.72 \\
\hline \multirow{2}{*}{ Average } & $\mathrm{x}$ & 61.65 & 61.43 & $64.13 *$ & $63.82^{*}$ & $64.36^{*}$ \\
& $\mathrm{~s}$ & 30.77 & 24.63 & 21.22 & 20.53 & 26.37 \\
\hline
\end{tabular}

* $\mathrm{P}<0.05$

Average total egg production per hen (number of eggs, laying capacity, egg mass) and per group (number of eggs and total mass of eggs) during the 150 days of trial is presented in Table 8 .

\section{Discussion}

Results related to average body mass and to average body mass gain (Table 3 ) show that the differences between control and experimental groups were statistically non-significant $(\mathrm{P}>0.05)$. The highest body mass gain was found in experimental group $\mathrm{E}_{4}$ (index $114.81 \%$ ), fed on sunflower meal with the addition of lysine and energy. Hens fed on energy-balanced 
Table 8

Average production of eggs during the trial (150 days)

\begin{tabular}{|l|l|l|l|l|}
\hline \multicolumn{2}{|l|}{} & \multicolumn{3}{|c|}{ Average per hen } \\
\hline Groups & $n$ & $\begin{array}{l}\text { Number of } \\
\text { eggs }\end{array}$ & $\begin{array}{l}\text { Laying } \\
\text { capacity \% }\end{array}$ & $\begin{array}{l}\text { Weight of } \\
\text { eggs g }\end{array}$ \\
\hline$C$ & 15 & 133.67 & 89.44 & 61.65 \\
\hline$E_{1}$ & 15 & 134.73 & 90.35 & 61.33 \\
\hline$E_{2}$ & 15 & 131.57 & 88.01 & 64.13 \\
\hline$E_{3}$ & 15 & 136.93 & 91.74 & 63.82 \\
\hline$E_{4}$ & 15 & 136.67 & 91.48 & 64.39 \\
\hline
\end{tabular}

sunflower meal $\left(\mathrm{E}_{2} 102.88 \%\right)$, amino acid balanced sunflower meal $\left(\mathrm{E}_{3} 103.70 \%\right)$ and the control group ( $100 \%)$, demonstrated approximately the same body mass gain. Laying hens fed on sunflower meal without amino acid and energy correction $\left(E_{1}\right)$ had a $17.7 \%$ smaller body mass gain than the control group, and smaller than the other experimental groups.

Results related to body mass gain are in complete accordance with the published data (Aleandri and Olivetti 1978; Kwayjan et al. 1983; Karunajeewa et al. 1989). Similar results were obtained in a number of experiments carried out on chicks (Valdivie et al. 1976, 1977; Valdivie and Hernandez 1980; Ologhobo 1991; Serman et al. 1996).

Average total feed consumption of the group fed on sunflower meal with added lysine and energy $(249.00 \mathrm{~kg})$ was about the same as in the control group $(249.60 \mathrm{~kg})$ - Table 4 . Experimental groups fed on sunflower meal without any correction $\left(\mathrm{E}_{1}\right)$ or with only energy correction $\left(\mathrm{E}_{2}\right)$ had an average feed consumption of $4.3 \%$ and $3.6 \%$ less than the control group. Hens fed on sunflower meal with the addition of lysine $\left(\mathrm{E}_{3}\right)$ consumed $3.5 \%$ more feed than the control group. Feed consumption per egg was highest in this group also. The lowest feed consumption was recorded in the group of hens fed on sunflower meal without corrections $\left(E_{1}\right)$. Similar results related to feed consumption was found by Karunajee wa et al. (1987) with White Leghorn hens.

All groups of hens had a similar average number of eggs (or average laying capacity), although the differences in average egg mass were statistically significant $(\mathrm{P}<0.05)$. Laying hens fed on sunflower meal without correction of energy and with no addition of lysine $\left(E_{1}\right)$, as well as the control group, had similar average egg mass (61. 43 and $61.65 \mathrm{~g})$, but differences between all other experimental groups and the control group were statistically non-significant $(\mathrm{P}>0.05)$. These results are in accordance with similar trials made by other authors (Srichai and Balnave 1981; Karunajeewa et al. 1989). However, results of research reported by Rose et al. (1972), show that the use of 50 and $100 \%$ sunflower meal in feed mixtures significantly decreased laying capacity and egg mass. Conversely, Mirza and Sial (1993) found that the use of sunflower meal in feed mixtures for laying hens had no significant effect on production results (laying capacity, egg mass, shell quality, mortality).

During the whole duration of the experiment no sickness or death was diagnosed.

\section{Využití slunečnicové moučky v krmných směsích pro nosnice}

Bylo sledováno nutriční využití proteinového přídavku slunečnicových pokrutin (44\% bílkovin) ve krmné směsi pro nosnice na produkci vajec. K pokusu bylo použito 75 nosnic (hybridní linie Issa brown) v průběhu prvých 150 dnů snůšky. Nosnice byly rozděleny do pěti skupin: kontrolní a 4 pokusných po 15 kusech. Kontrolní skupina byla krmena 
kompletní komerční směsí s obsahem kukuřice, soji a rybí moučky. Pokusné krmení směsi obsahovaly slunečnicové pokrutiny (moučku) $\mathrm{s}$ korekcí obsahu energie prridáním slunečnicového oleje $\left(E_{2}\right)$, slunečnicové moučky s lyzinem $\left(E_{3}\right)$ a slunečnicové moučky s úpravou obsahu energie i lyzinu.

Nejvyšší produkce vajec byla ve slupinách $E_{3}$ a $E_{4}$. Nejnižšší konzum krmiva byl zjištěn ve skupině $E_{1}$, zatímco nejvyšší byl nalezen ve skupinách $E_{3}$ a $C$. Největší přírůstky hmotnosti byly ve skupině $E_{4}$. Deficience lyzinu ve slunečnicové moučce $\left(E_{1}\right)$ se projevila nižší hmotností, konzumem krmiva a hmotností vajec. Zkrmování směsi s obsahem kukuřičné moučky jako př́idavkem bílkovin nemhlo vliy na zdravotní stav ani mortalitu nosnic. Výsledky pokusu ukazují. že kukuriičnou moučku lze úspěšně využít ve výživě nosnic. je-li v krmné směsi vyvážen obsah energie a lyzinu.

\section{References}

ALEANDRI, M., OLIVETTI, A. 1978: Miscele vegetali nell alimentazione delle polastre e delle ovaiole in bateria. Avicoltura 47: 27-34

A. O. A. C. 1984: Official Methods of Analysis (14th Ed.). Association of Official Analytical Chemists, Arlington, VA, USA

CUCA, M., AVILA. E., SOSA, E. 1973: Threonine supplementation to sunflower diets for chicks. Poultry Sci. 52: 2016-2017

DEATON. J. W., McNAUGHTON, J. L., BLRDICK, D. 1979: High-fibre sunflower meal as a replacement for soybean meal in layer diets. British Poultry Sci. 20: 159-162

KASHANI, A. B., CARLSON, C. W. 1988: Use of sunflower seeds in grower diets for pullets and subsequent performance as affected by aureomycin and pelleting. Poultry Sci. 67: 445-451

KARUNAJEEWA, H., ABU-SEREWA, S., THAM, S. H., EASON, P. 1987: The effects of dietary level of sunflower seeds and lysine on egg quality and laying performance of White Leghorn hens. J. Sci. Food and Agriculture 41: 325-333

KARUNAJEEW A. H., THAM, S. H., ABU-SEREWA, S. 1989: Sunflower seed meal, sunflower oil and full-fat sunflower seed, hulls and charnels for laying hens. Animal feed Sci.Technology 26: 45-54

KWAYJAN, M. G.. AZAR, E. J., DAGHIR, N. J. 1983: Sunflower seed in laying hen rations. Poultry Sci. 62: $1247-1253$

MICHEL, J. N.. SUNDE, M. L. 1985: Sunflower meals in pullet developer diets. Poultry Sci. 64: 669-674

MIRZA, M. A., SIAL, M. A. 1993: Sunflower meal as a major vegetable protein source in layers ration. Arch. Anim. Nutr. 42: 273-277

NATHANAEL, A. S., SELL. J. L. 1980: Quantitative measurements of the lysine requirement of the laying hen. Poultry Sci. 59: 594-597

OLOGHOBO. A. D. 1991: Substitution of sunflower seed meal for soybean meal and groundnut meal in practical broiler diets. Arch. Anim. Nutr. 41: 513-520

RAMIREZ, J. L., CUCA. G. M., AVILA, G. E. 1974: Pasta de girasol (Helianthus annus) para polas de reemplazo y postura. Asociacion Latinoamericana de produccion animalmemoria 9: 269-280

ROSE, R. J.. COIT, R. N., SELL, J. L. 1972: Sunflower seed meals a replacement for soybean meal protein in laying hen rations. Poultry Sci. 51: 960-967

SPATZ, C. 1997: Basic Statistics. 6th ed. Brooks/Cole Publishing Company. 511 Forest Lodge Road. Pacific Grove, Ca 93950

SRICHAI, Y., BALNAVE, D. 1981: Egg weight responses to dietary supplementation with sunflower oil and rice pollard. Australian Journal of Agricultural Research 32: 183-188

SULJOTI, L. 1986: Mundësia e lëvendësimit të miellit të peshkut me bërsi soje dhe bërsi luledielli pjesërisht të zhveshur nëtë ushqyerit e pulave për vezé qü mbahen në bateri. Buletini i shkencave Zooteknike e Veterinare 4: 21-29

SERMAN, V., GOJEVIC-ZRNIC, F., DUMANOVSKY, F., MAS, N., MIKULEC, Ž., MELENJUK, V.1996: Use of sunflower meal in feed mixtures for fattening chicks. I. Influence on the performance of fattening chicks. Vet arhiv 66: $13-26$

SOKAROVSKI, J., FILEV, K., JORDANOSKI, N. 1988: Alternativna krmiva za kukuruz i sojinu sa\#mu u ishrani nosilja. Peradarstvo 23: 11-12, 50-55

VALDIVI, M., ARAGON, E., JORDAN, H. 1976: Broiler diets with high contents of sunflower seed meal and different energy:protein rations. Cuban J. Agricultural Sci. 10: 297-304

VALDIVI, M., ARAGON, E., JORDAN, H. 1977: Substitution of fish meal and /or soybean meal by a mixture of torula yeast and sunflower seed meal in broiler rations. Cuban J. Agricultural Sci. 11: 201-207 
VALDIVI, M., HERNANDEZ, J. 1980: Substitution of soybean meal by combination of torula yeast: sunflower seed meal in diets for fattening chickens. Cuban J. Agricultural Sci. 14: 145-151

VIEIRA, S. L., PENZ, A. M. Jr., LEBOUTE, E. M., CORTELINE, J. 1992: A nutritional evaluation of a high fibre sunflower meal. J. Applied Poultry Research 1: 382-388

Address for correspondence

Prof. dr. sci. Vlasta Šerman

Faculty of Veterinary Medicine

Heinzelova 55

10000 Zagreb

CROATIA

Phone: 38512390270

Fax: 3851214697 